\title{
Os maiores eventos esportivos do planeta no Brasil e a Pesquisa em Educação Física e Esporte
}

http://dx.doi.org/10.1590/1807-55092014000200195

O Brasil é a sede da Copa do Mundo da FIFA de 2014. Em 2016, será a vez da cidade do Rio de Janeiro ser o centro das atençóes do esporte mundial, sediando os Jogos Olímpicos. Mais do que estádios modernos, milhões de espectadores, atletas extraordinários e certamente performances inesquecíveis, teremos (ou teríamos?) a oportunidade de colocar no foco de nossas discussôes a importância, relevância, significado e contribuição da Ciência do Esporte. Profissionais de Educação Física e Esporte, Pesquisadores, Acadêmicos, Professores, Praticantes e Treinadores poderiam (o farão?), cada um a seu modo, e norteados por interesses pessoais e profissionais, levantar inúmeras questóes concernentes a esse grandioso fenômeno sociocultural, político, esportivo e econômico, nomeadamente ESPORTE. E a Ciência do Esporte? E a produção do conhecimento específico na área de Educação Física e Esporte? $\mathrm{E}$ as agências de fomento nesse cenário? $\mathrm{E}$ os programas de Pós-Graduação, juntamente com seus requisitos e normas direcionados a atender os critérios balizadores das avaliaçóes? E os Editais para o Esporte de Alto Rendimento e seus critérios (ou falta deles?) para avaliar a "relevância" dos projetos nessa área? E o futuro de nossa área enquanto área acadêmica? Certamente, essas, e muitas outras questôes farão (deveriam fazer...) parte de calorosas discussóes e argumentaçóes de toda a comunidade acadêmica. Apesar de estarmos longe de um consenso, é razoável admitir que muitas das respostas às perguntas formuladas, poderão, em maior ou menor grau, nos levar a um entendimento de que há, no momento, uma forte ameaça ao distanciamento entre as características dos projetos de pesquisa desenvolvidos (e apoiados, fomentados...) e seus respectivos objetos de investigação (e em consequência, de nossa produção científica) com a área específica da Educação Física e do Esporte. Adicionalmente, alguns poderão também identificar certa desconfiança e desmotivação por parte dos pesquisadores mais jovens, ou mesmo daqueles ainda em formação, em caminhar no sentido da investigação de objetos realmente inerentes a área da Educação Física e do Esporte, particularmente no que concernem aqueles mais próximos da realidade e do campo profissional (será que vale a pena?...). Muitas explicações para tal distanciamento, (des)motivação, ou falta de encorajamento para tanto, poderiam ser expostas; desde, por exemplo, a identificação por parte dos pesquisadores em Educação Física e Esporte, de que os consultores (nós mesmos; nossos pares...) de agências de fomento não veem, geralmente, com "bons olhos" o desenvolvimento desses projetos, e, portanto, emitem pareceres desfavoráveis; em adição, poder-se-ia concluir que a produção intelectual na área específica terá que ser realizada (divulgada, disseminada), em grande parte, nos periódicos com menores "fatores de impacto", o que em última instância, poderia afetar interesses de todos os "graus de liberdade" do sistema vigente e assim desestimular a pesquisa em nossa área. Apesar da importância de uma discussão mais aprofundada e permanente dessa questấo, ainda pouco se tem caminhado nesse sentido. Precisamos não somente discutir a questáo com maior profundidade, mas também, deveríamos não medir esforços para avançar no desenvolvimento e consolidação das pesquisas em nossa verdadeira área de atuação, acadêmica e profissional, legitimando nossa identidade acadêmica e da própria profissão. Estudos com metodologias e intervenções que tenham forte e relevante influência no campo profissional e no dia a dia dos profissionais da Educação Física e do Esporte devem ser fomentados e desenvolvidos. Assessores, Pareceristas e Editores de periódicos, Avaliadores de Programas e os próprios Programas de PósGraducação em Educação Física e Esporte poderiam, neste momento, refletir sobre um possível legado dos grandes eventos realizados em nosso País. O legado de uma identidade acadêmica, forte e relevante para o campo profissional, com produçáo de conhecimento de qualidade e alinhado com nossas demandas. Para tanto, é preciso estímulo, apoio, reconhecimento e motivação entre e de nossa própria comunidade acadêmica.

Prof. Dr. Alexandre Moreira

Blog da RBEFE - http://rbefe.blogspot.com.br Facebook - http://www,facebook.com/reveefe Twitter - https://twitter.com/RBEFE 